\title{
Incidence of surgical infection and risk factors in colorectal surgery - A prospective cohort study
}

\author{
Incidencia de infección quirúrgica y factores de riesgo en cirugía colorrectal. Estudio de \\ cohorte prospectivo
}

\author{
Javier Páramo-Zunzunegui,', Marcos Alonso-García³, Diego Rodríguez-Villar ${ }^{3}$, \\ Justina Drewniak-Jakubowska', Pablo Calvo-Espino ${ }^{1}$, Rosa Cuberes-Montserrat', \\ Gil Rodríguez-Caravaca ${ }^{3,4}$, and Manuel Durán-Poveda ${ }^{5}$
}

${ }^{1}$ Department of General and Digestive System Surgery, Hospital Universitario de Móstoles; ${ }^{2}$ International Doctoral Program, Universidad Rey Juan Carlos; ${ }^{3}$ Preventive Medicine Unit, Hospital Universitario Fundación Alcorcón; ${ }^{4}$ Department of Preventive Medicine and Public Health, Faculty of Health Science, Universidad Rey Juan Carlos; ${ }^{5}$ Department of General and Digestive System Surgery, Hospital Universitario Rey Juan Carlos. Madrid, Spain

\begin{abstract}
Objective: The objective was to measure the incidence of surgical site infection (SSI) and identify risk factors, in patients undergoing elective surgery of the colon and rectum. Materials and methods: A prospective cohort study was performed from January 2017 to December 2018. Results: A total of 130 patients were studied. The cumulative incidence of SSI was $12.3 \%$. The $56.25 \%$ were superficial wound infections and the $31.25 \%$, organ-space infection. The risk factors significantly associated with SSI were the non-administration of pre-operative oral nutrition, diabetes mellitus, heart disease, symptomatic state at the diagnosis of colorectal cancer (CRC), and $\geq 2$ altered nutritional biochemical parameters at diagnosis. After multivariate, risk factors associated with SSI were: non-administration of preoperative enteral nutrition (odds ratio $[O R]=0.27 ; 95 \%$ confidence interval [CI]: 0.07-1.0), $D M(O R=3.0 ; 95 \% \mathrm{Cl}: 0.9-9.9)$, the heart disease (OR $=4.6 ; 95 \% \mathrm{Cl}: 1.1-18.6)$, and laparoscopic surgery (OR $=0.28 ; 95 \% \mathrm{Cl}: 0.08-0.97)$. The average stay was higher in patients with a diagnosis of SSI (11.9 vs. 9.2 days). Conclusions: Independent risk factors for SSI in CRC were the non-administration of pre-operative enteral nutrition, the existence of heart disease, and open surgery.
\end{abstract}

Key words: Surgical site infection. Colorectal surgery. Surgical wound infection. Incidence. Risk factors. Cohort study.

\section{Resumen}

Objetivo: Estudiar la incidencia de infección del sitio quirúrgico y evaluar sus factores de riesgo en pacientes intervenidos de cirugía colorrectal electiva. Método: Se realizó un estudio de cohortes prospectivo desde enero de 2017 hasta diciembre de 2018. Resultados: Se incluyeron 130 pacientes. La incidencia acumulada de infección del sitio quirúrgico fue del 12,3\% ( $n=16)$, siendo el 56,25\% infecciones de herida y el 31,25\% infecciones órgano-espacio. Los factores de riesgo asociados a infección del sitio quirúrgico con significación estadística fueron la no administración de nutrición oral preoperatoria, la diabetes mellitus, la enfermedad cardiaca, la presencia de síntomas en el momento del diagnóstico de cáncer colorrectal y tener al menos dos parámetros bioquímicos nutricionales alterados. Tras el análisis multivariante se asociaron la no administración de nutrición

\footnotetext{
Correspondence:

*Javier Páramo-Zunzunegui

Luis Montes, $\mathrm{s} / \mathrm{n} \quad$ Date of reception: 20-03-2020

C.P. 28935, Móstoles, Madrid, Spain Date of acceptance: 25-04-2020

E-mail: Javier.paramo@salud.madrid.org

DOI: $10.24875 / C I R U .20000205$

Cir Cir. 2021;89(2):156-162

Contents available at PubMed

www.cirugiaycirujanos.com

0009-7411/@ 2020 Academia Mexicana de Cirugía. Published by Permanyer. This is an open access article under the terms of the CC BY-NC-ND license (http://creativecommons.org/licenses/by-nc-nd/4.0/).
} 
enteral preoperatoria (odds ratio $[O R]=0,27$; intervalo de confianza del $95 \%$ [IC95\%]: 0,07-1,0), la diabetes mellitus (OR = 3,0; IC95\%: 0,9-9,9), la enfermedad cardiaca (OR = 4,6; IC95\%: 1,1-18,6) y la cirugía laparoscópica (OR = 0,28; IC95\%: 0,08-0,97). La estancia media fue mayor en los pacientes con diagnóstico de infección del sitio quirúrgico (11,9 frente a 9,2 días). Conclusiones: Los factores de riesgo independientes para el desarrollo de infección del sitio quirúrgico en los pacientes con cáncer colorrectal fueron la no administración de nutrición oral preoperatoria, la enfermedad cardiaca y la cirugía abierta.

Palabras clave: Infección del sitio quirúrgico. Cirugía colorrectal. Infección de herida quirúrgica. Incidencia. Factores de riesgo. Estudio de cohortes.

\section{Introduction}

A healthcare-associated infection (HCAl) is an infection occurring in a patient during the process of care in a hospital or other health-care facility ${ }^{1}$. These infections first appear 3 days or more after admission, considered day 1. Any infections the patient already had at the time of admission are excluded, except when a change in pathogen or symptoms suggests the acquisition of a new infection².

HCAI is a primary public health concern, which falls within the lines of monitoring and control defined by the European Commission and the European Centre for Disease Control (ECDC), urging countries to adopt and implement strategies for the prevention and control of $\mathrm{HCAl}^{3}$. According to the ECDC, the prevalence of $\mathrm{HCAl}$ is $6.5 \%$ in European hospitals ${ }^{4}$. Surgical site infection (SSI) has a significant impact on HCAls. According to the EPINE study, SSI is the main cause of HCAI $(21.6 \%)$, ahead of respiratory and urinary tract infections ${ }^{5}$. SSIs are usually caused by an imbalance between bacteria and the body's defenses, and their development is, therefore, related to many endogenous and exogenous factors ${ }^{6-10}$. The most important related factors include type of surgery, degree of contamination, duration of surgery, comorbidities, age, American Society of Anaesthesiologists (ASA) classification, nutritional status, and obesity ${ }^{11,12}$. An estimated $60 \%$ of SSIs are preventable $^{6}$. The Indicators of Continuous Quality Improvement (INCLIMECC) program of continuous surveillance of hospital infection ${ }^{7}$ has observed CSI rates of $17.1 \%$ in colon surgery and $21.36 \%$ in rectal surgery ${ }^{8}$.

Knowledge of the factors that influence the development of SSI in colorectal surgery can encourage the adoption of corrective measures to prevent its occurrence $^{9}$. The aim of this paper was to study the incidence of infection in surgical sites and to evaluate risk factors in patients undergoing elective colon and rectal surgery.

\section{Materials and Methods}

A prospective cohort study was conducted at the Hospital Universitario de Móstoles (Madrid, Spain). The study included patients undergoing colon and/or rectal surgery in the general and digestive surgery department from January 2017 to December 2018. The study was approved by the Hospital Universitario de Móstoles Clinical Research Ethics Committee. Patients with suspected infection at the time of surgery or undergoing antibiotic treatment, those receiving neoadjuvant therapy, and patients with no primary anastomosis and emergency surgery were excluded from the study. An estimate of the sample size was made according to a $95 \%$ confidence, an accuracy of $4.5 \%$, an estimate of infection rate of $10 \%$, and predicting a $5 \%$ loss. Based on these premises, a study sample of 130 patients was considered necessary. Patients were selected from the surgical schedule and were included by consecutive inclusion from the beginning until the end of the study period. The evolution of the patients from the moment of surgery to the end of the maximum incubation period of 30 days was studied. The criteria of the Centers for Disease and Prevention Control (CDC) were used for the diagnosis of SSI and the Clavien-Dindo classification for the rest of the surgical complications.

The variables included in the study were age, sex, body mass index (BMI), ASA classification, high blood pressure (HBP), diabetes mellitus (DM), chronic obstructive pulmonary disease (COPD), heart disease, taking antiplatelet agents, taking oral anticoagulants, hypothyroidism, taking anticoagulants, weight loss related to diagnosis, nutritional risk according to the MUST tool, analytical parameters and degree of alteration thereof, duration of surgery, blood transfusion, type of surgical intervention, symptomatic status at diagnosis, and adequacy of preoperative prophylactic measures. The dependent variable in our work was the diagnosis of SSI. 
A specific database was designed for data collection and a relational database and standardized with the Microsoft Access ${ }^{\circledast}$ program for recording them. A descriptive study of the sample was carried out. Quantitative variables were described with the mean and standard deviation (SD) or median and interquartile range (IRQ) if they did not follow a normal distribution. They were compared with the Student's t-test and if they did not follow normal distribution, the Mann-Whitney U-test was used. Quantitative variables with more than 2 categories were compared with the analysis of variance (ANOVA) and if their application conditions were not met, the non-parametric Kruskal-Wallis test was used. Qualitative variables were described with their frequency distribution and compared with Pearson's Chi-square test or Fisher's exact test if the application criteria were not met. The cumulative incidence of SSI and the influence on its appearance as risk factors of the different variables under study were evaluated. The statistical and epidemiological analysis was performed with the SPSS v.22 and Epidat v.4.2 programs. Statistically significant differences were considered to be those with $p<0.05$ and all estimates were described with their $95 \%$ confidence interval $(\mathrm{Cl})$.

\section{Results}

Most patients were classified as ASA II (60\%) and ASA III (34.6\%). The most frequent comorbidities of the patients were HBP (55.4\%), dyslipidemia (DL) (40\%), and DM type I (17.7\%). A total of $13.1 \%$ of the patients had heart disease (heart failure, atrial fibrillation, or coronary disease) and $13.8 \%$ had COPD. The BMI in the total population studied had an average of $27.5(\mathrm{SD}=4)$. The characteristics of the patients are described in table 1.

According to the symptoms of the patients at the time of diagnosis, a distinction was made between those patients who had a clinical history related to the disease and those who came from the Prevecolon screening campaign and were, therefore, asymptomatic. Overall, $29 \%$ of patients $(n=37)$ came from the screening campaign and were asymptomatic, while $71 \%(n=93)$ were symptomatic. A total of $51.5 \%$ were overweight and $24.6 \%$ were obese. In the group, it was found that $33 \%(n=43)$ of the patients had no weight loss, $18.5 \%(n=24)$ lost $<5 \mathrm{~kg}, 25.4 \%(n=33)$ lost between 5 and $10 \mathrm{~kg}$, and $2.3 \%(n=3)$ lost $\geq 10 \mathrm{~kg}$. Weight loss was higher in the group of patients not from the screening campaign ( $p=0.016$ ).

The pathological study in the first consultation was as follows: adenocarcinoma in $71.5 \%(n=93)$, tubular adenoma with unresectable dysplasia in $14.6 \%(n=19)$, and tubulovillous adenoma with unresectable dysplasia in $13.8 \%(n=18)$. In the general population studied, $36.2 \%(n=47)$ had the neoplasm located in the right colon, 33.8\% ( $n=44)$ in the left colon, 20.8\% $(n=27)$ in sigma, 6.9\% $(n=9)$ in the rectum, and $2.3 \%(n=3)$ with location in the transverse colon. About 93\% (121) of patients underwent surgery for colon neoplasia and $7 \% 9$ underwent rectal surgery. Despite the small number of rectal procedures, we have not found differences in the distribution by population group.

Open surgery was used in $36.2 \%(n=47)$ of the operations, laparoscopic surgery in $53.1 \%(n=69)$, and the procedure could not be completed by laparoscopy in $10.8 \%(n=14)$ and had to be reconverted to laparotomy. The mean surgery time was $227.9 \mathrm{~min}$ $(S D=63)$ and the median was 217.5.

The alteration of analytical parameters was also assessed as a possible risk factor associated with SSIs. The mean and frequency distribution of these groups is detailed in table 2 .

There were a total of 9 patients $(6.9 \%)$ with superficial and/or deep incision infection, 5 (3.8\%) with organ/space infection, and $2(1.5 \%)$ with combined wound and organ/space infection. This resulted in an overall incidence of SSI of $12.3 \%$. When studying the average hospital stay of patients (in days) as they developed SSIs, we found that the average stay is 9.2 days $(S D=6.8)$ for the group of patients with no infection, slightly lower than that of patients with SSI, which is 11.9 days $(S D=6.1)$, although with $p=0.6$. The results are not statistically significant.

In the univariate analysis, the risk factors associated with SSIs were the absence of pre-operative oral enteral nutrition administration, DM, heart disease, diagnosis with symptoms secondary to the neoplastic disease, and having more than 2 altered biochemical nutritional parameters.

In the multivariate analysis, we studied the independent risk factors of SSI, statistically significant after the univariate analysis, and those with significance $\leq 0.2$ that were considered relevant because of their clinical and prognostic significance (age, sex, application of the plan, DM, ATH, heart disease, chronic lung disease, BMI, weight loss, surgical technique, symptomatic state at diagnosis, albumin deficit, total protein deficit, and degree of alteration of analytical parameters). After the multivariate analysis, the following were statistically significant: the administration of preoperative enteral nutrition (OR $=0.27$; IC 95\%: 0.07-1.0), DM (OR = 3.0; IC 95\%: 0.9-9.9), previous heart disease (OR $=4.6$; IC 95\%: 1.1-18.6), and 
Table 1. Description and characteristics of patients

\begin{tabular}{|c|c|}
\hline \multicolumn{2}{|l|}{ Gender, n (\%) } \\
\hline Male & $85(65)$ \\
\hline Female & $45(35)$ \\
\hline Age \pm SD (años) & $70,9 \pm 8$ \\
\hline \multicolumn{2}{|l|}{ Comorbidities, n (\%) } \\
\hline $\mathrm{HBP}$ & $72(55,4)$ \\
\hline Diabetes mellitus & $23(17,7)$ \\
\hline Dyslipidemia & $52(40)$ \\
\hline Cardiac disease & $17(13,1)$ \\
\hline COPD & $18(13,8)$ \\
\hline Thyroid disease & $14(10,8)$ \\
\hline \multicolumn{2}{|l|}{ Toxic habits, n (\%) } \\
\hline Active smoker & $16(12,3)$ \\
\hline Former Smoker & $65(50)$ \\
\hline Non-smoker & $49(37,7)$ \\
\hline \multicolumn{2}{|l|}{ No alcohol consumption } \\
\hline Alcohol occasional & $26(20)$ \\
\hline Alcohol moderate & $31(23,8)$ \\
\hline Alcohol abuse & $2(1,5)$ \\
\hline \multicolumn{2}{|l|}{ ASA, n (\%) } \\
\hline ASA IW & $5(3,8)$ \\
\hline ASA II & $78(60)$ \\
\hline ASA III & $45(34,6)$ \\
\hline ASA IV & $2(1,5)$ \\
\hline $\mathrm{BMI} \pm \mathrm{SD}$ & $27,5 \pm 4$ \\
\hline \multicolumn{2}{|l|}{ Weight loss, n (\%) } \\
\hline No weight loss & $43(33)$ \\
\hline Weight loss $\leq 5$ kg & $24(18,5)$ \\
\hline Weight loss 5-10 kg & $33(25,4)$ \\
\hline Weight loss $\geq 10 \mathrm{~kg}$ & $3(2,3)$ \\
\hline Not asked & $27(20,7)$ \\
\hline \multicolumn{2}{|c|}{ Symptomatic status at diagnosis, $n(\%)$} \\
\hline Asymptomatic (screening) & $37(29)$ \\
\hline Symptomatic & $93(71)$ \\
\hline \multicolumn{2}{|l|}{ Neoplasm location } \\
\hline Right colon neoplasm & $47(36,2)$ \\
\hline Left colon neoplasm & $44(33,8)$ \\
\hline Sigma neoplasm & $27(20,8)$ \\
\hline Rectum neoplasm & $9(6,9)$ \\
\hline Transverse colon neoplasm & $3(2,3)$ \\
\hline \multicolumn{2}{|l|}{ Surgical technique, n (\%) } \\
\hline Open & $47(36,2)$ \\
\hline Laparoscopy & $69(53,1)$ \\
\hline Reconverted laparoscopy & $14(10,8)$ \\
\hline Duration of surgery $\pm \mathrm{SD}$ & $227,9 \pm 63$ \\
\hline
\end{tabular}

laparoscopic surgery (OR = 0.28; IC95\%: 0.08-0.97). Table 3 details the univariate and multivariate analysis for the various risk factors for SSI.

\section{Discussion}

There is scientific evidence of the influence that several modifiable and non-modifiable risk factors

\section{Table 2. Analytical parameters}

\begin{tabular}{lc}
\hline Analytical parameters $\pm \mathrm{SD}$ & \\
Hemoglobin $(\mathrm{g} / \mathrm{dl})$ & $13,2 \pm 2.2$ \\
Lymphocytes & $2,53 \pm 2,16$ \\
Albumin $(\mathrm{g} / \mathrm{dl})$ & $4,2 \pm 0,6$ \\
Pre-albumin $(\mathrm{mg} / \mathrm{dl})$ & $26,2 \pm 18,5$ \\
Total proteins $(\mathrm{g} / \mathrm{dl})$ & $6,7 \pm 0,73$ \\
Retinol bound protein $(\mathrm{mg} / \mathrm{dl})$ & $4,3 \pm 0,98$ \\
Cholesterol $(\mathrm{mg} / \mathrm{dl})$ & $168 \pm 39$ \\
Transferrin & $256,5 \pm 61$ \\
& \\
Total number of altered analytical parameters, $\mathrm{n}(\%)$ & \\
Non altered parameters & $28(21,5)$ \\
1-2 altered parameters & $80(61,5)$ \\
$>2$ altered parameters & $22(17)$ \\
\hline
\end{tabular}

Table 3. Univariate and multivariate analysis of ISQ risk factors

\begin{tabular}{|c|c|c|c|}
\hline Univariate analysis & SSI & No SSI & $\mathrm{p}$-value \\
\hline Pre-operative oral nutrition & $12(18,5 \%)$ & $53(81,5 \%)$ & 0,033 \\
\hline DM & $8(24,2 \%)$ & $25(75,8 \%)$ & 0,16 \\
\hline Cardiac disease & $5(29,4 \%)$ & $12(70,6 \%)$ & 0,02 \\
\hline Albumin deficit & $2(28,6 \%)$ & $5(71,4 \%)$ & 0,21 \\
\hline Pre-albumin deficit & $1(8,3 \%)$ & $11(91,7 \%)$ & 0,90 \\
\hline Total proteins deficit & $6(20 \%)$ & $24(80 \%)$ & 0,18 \\
\hline $\begin{array}{l}\geq 2 \text { altered analytical } \\
\text { parameters* }\end{array}$ & $16(12,3 \%)$ & $114(87,7 \%)$ & 0,04 \\
\hline Symptomatic patients & $16(17,2 \%)$ & $77(82,8 \%)$ & 0,007 \\
\hline Age $\geq 70$ years & $11(16,2 \%)$ & $57(83,8 \%)$ & 0,16 \\
\hline Male gender & $9(10,9 \%)$ & $76(89,1 \%)$ & 0,4 \\
\hline $\mathrm{HBP}$ & $10(13,9 \%)$ & $62(86,1 \%)$ & 0,54 \\
\hline COPD & $2(11,1 \%)$ & $16(88,9 \%)$ & 0,87 \\
\hline Weight loss & $13(14,8 \%)$ & $75(85,2 \%)$ & 0,22 \\
\hline$A S A \geq I I I$ & $7(14,9 \%)$ & $40(85,1 \%)$ & 0,5 \\
\hline $\mathrm{BMI} \geq 30$ & $13(12,4 \%)$ & $22(88 \%)$ & 0,96 \\
\hline Open surgery & $5(7,2 \%)$ & $64(92,8 \%)$ & 0,06 \\
\hline Surgical duration $\geq 150 \mathrm{~min}$ & $15(12,8 \%)$ & $102(87,2 \%)$ & 0,28 \\
\hline Multivariate analysis & OR & IC $95 \%$ & $\mathrm{p}$-value \\
\hline Pre-operative oral nutrition & 0,27 & $0,07-1,01$ & 0,05 \\
\hline DM & 2,99 & $0,91-9,87$ & 0,07 \\
\hline Cardiac disease & 4,57 & $1,12-18,64$ & 0,03 \\
\hline Laparoscopic surgery & 0,28 & $0,08-0,97$ & 0,04 \\
\hline
\end{tabular}

have on the development of post-operative complications, including SSI, after colon and rectal surgery ${ }^{13}$. 
An overall rate of SSI of $12.3 \%$ was observed in our study.

Patients were monitored during the 30 days postoperative period. Some studies limit SSI monitoring to the period of hospitalization rather than 30 days after surgery, which may underestimate its incidence ${ }^{14,15}$.

The rate of SSIs recorded in our study is low when compared with other studies, such as the Community of Madrid's multicenter INCLIMECC Task Force study, which observed overall SSI rates of $17.1 \%$ in colon surgery and $21 \%$ in rectum surgery. The VINCat study observed an incidence of $20.8 \%$ in colorectal surgery. In international literature, several studies such as Poon et al. describe lower rates of SSI $(6.5 \%)^{16}$. Gianotti et al. observed an incidence of $13.4 \%^{17}$. Howard et al. reported a $7 \%$ incidence of SSI for laparoscopic surgery and $25 \%$ for open surgery ${ }^{18}$.

A total of $6.9 \%$ presented superficial and/or deep incisional SSI, 3.8\% organ/space infection, and 1.5\% presented SSI in both spaces.

There is a high level of variability of significant risk factors for SSI in the studies analyzed. Most of the risk factors acknowledged in the literature were evaluated in our study. In the univariate study, we found statistical significance for the incorrect administration of nutritional support protocol, DM, heart disease, diagnosis with symptoms, and having more than 2 altered nutritional biochemical parameters. After the multivariate study, only the incorrect application of the nutritional assessment program, the surgical approach, and heart disease were found.

In our study, we observed a SSI rate of $21.3 \%$ $(n=10)$ in open surgery, $7.2 \%(n=5)$ in laparoscopic surgery, and $7.1 \%(n=1)$ in the group with reconverted surgery, with no statistically significant difference between the groups with $p=0.064$. However, in the multivariate study, laparoscopic surgery is a protective factor for the development of SSI with an $\mathrm{OR}=0.28$, IC 95\% 0.08-0.97, $p=0.04$. A Japanese retrospective cohort study of 9655 patients observed that laparoscopic surgery is a protective factor against SSI compared to open surgery ${ }^{19}$. These findings are consistent with those of Poon et al. (2009) and Kiran et al. $(2010)^{16,20}$.

A decrease in the incidence of SSIs was found in those patients given pre-operative oral nutrition (OR = 0.29, Cl95\%: 0.09-0.95) $(p=0.033)$. However, and following the multivariate study, we observed that this fact protects against SSI with an OR of 0.27 and a
$95 \% \mathrm{Cl}$ of $0.07-1.01$ and value of $\mathrm{p}=0.05$. Therefore, the result requires a non-categorical interpretation. We believe that other factors may have influenced the decrease in the risk of SSIs. After reviewing scientific studies, we found Spanish papers that refer to these findings. The study by Barreiro et al. shows a reduction in SSI from $1.9 \%$ to $0.8 \%{ }^{21}$ and Manzanares et al. reported a reduction in SSI from $40 \%$ to $33 \%$.

There is a widespread perception that DM is associated with increased tissue and organ susceptibility to the development of certain infections ${ }^{23}$. Several, the majority retrospective observational studies, identified DM as an independent factor for the development of SSIs in univariate and multivariate studies $^{24,25}$. Other studies have not found such a relationship ${ }^{26-30}$. In our database, we identified that $17 \%(n=23)$ suffer from type I DM and $8 \%(n=10)$ from type II DM. Overall, $25 \%$ of the population studied was diagnosed with DM. These figures are slightly higher than those published by the Diabetes Foundation, which establishes a prevalence of DM for those over 18 years of age at $13.8 \%^{31}$. This considerable difference may be conditioned by the fact that the range of patients diagnosed with colorectal neoplasia is greater than the general population when studying the general prevalence of disease. In our multivariate study, we observed an OR 2.99 (95\% $\mathrm{Cl} 0.91-9.87, \mathrm{p}=0.07$ ) when studying DM as a risk factor for the development of SSI.

We found heart disease to be a risk factor for the development of SSIs with an OR $=4.57,95 \% \mathrm{Cl} 1.12$ 18.64 and $p=0.03$ in the univariate and multivariate studies. Patients previously diagnosed with heart disease (coronary heart disease or heart failure), COPD, or other comorbidities have a worse immediate postoperative evolution and also, in general terms, their clinical condition may lead to a limited therapeutic approach to their oncological disease and consequently a worse survival rate ${ }^{32}$. In a systematic review by Boakye et al., heart disease was associated with an increased risk of mortality for patients with moderate or severe comorbidity before surgery, with an $\mathrm{OR}=1.71,95 \% \mathrm{Cl}=1.26-2.31$ and $\mathrm{OR}=2.62,95 \%$ $\mathrm{Cl}=1.97-3.47$, respectively ${ }^{33}$. In our case, after the multivariate study for heart disease, although statistically significant, we observed a wide $\mathrm{Cl}$. This may be secondary to the sample size and the fact that the prevalence of disease in our study population was $13 \%(n=17)$. Perhaps, an enlargement of the sample size would have helped to reduce this interval. 
In the univariate study, we found that the risk of having SSI with previous diagnosis of nutritional analytical parameters deficit of $\geq 2$ is $12.3 \%$ with $p=0.04$. These findings have not been demonstrated in multivariate analysis, so we are unable confirm that, in isolation, the degree of analytical alteration increases the risk of SSI.

\section{Conclusions}

The incidence of SSI in colorectal surgery in our study was low (12.3\%). The risk factors associated with a higher probability of developing SSIs were as follows: the administration of a pre-operative nutritional assessment and support protocol and the existence of heart disease. We found the laparoscopic surgery as a protective factor for the development of SSI. The average hospital stay was higher in patients diagnosed with SSI (11.9 vs. 9.2 days), which was not statistically significant. It is important to evaluate risk factors for the development of pre-operative SSIs and to adopt preventive measures in those factors that are potentially modifiable to minimize their incidence and impact.

\section{Acknowledgments}

The authors thank to their colleagues at "Hospital Universitario de Móstoles" for always offering quality and humanity in their patient care.

\section{Conflicts of interest}

The authors declare have no conflicts of interest.

\section{Ethical disclosures}

Protection of human and animal subjects. The authors declare that no experiments were performed on humans or animals for this study.

Confidentiality of data. The authors declare that they have followed the protocols of their work center on the publication of patient data.

Right to privacy and informed consent. The authors declare that no patient data appear in this article.

\section{References}

1. Friedman ND, Kaye KS, Stout JE, McGarry SA, Trivette SL, Briggs JP, et al. Health care-associated bloodstream infections in adults: a reason to change the accepted definition of community-acquired infections. Ann Intern Med. 2002;137:791-7.
2. European Commission. Commission Implementing Decision of 8 August 2012 Amending Decision 2002/253/EC Laying Down Case Definitions for Reporting Communicable Diseases to the Community Network Under Decision No 2119/98/EC of the European Parliament and of the Council (2012/506/EU). Official Journal of the European Union. Luxembourg: Publications Office of the European Union; 2012. p. L262.

3. Serrano M, Barcenilla F, Limón E. Infección nosocomial en centros sanitarios de cuidados prolongados. Enferm Infecc Microbiol Clín. 2014; 32:191-8

4. Suetens C, Latour K, Kärki T, Ricchizzi E, Kinross P, Moro ML, et al. Prevalence of healthcare-associated infections, estimated incidence and composite antimicrobial resistance index in acute care hospitals and long-term care facilities: results from two European point prevalence surveys, 2016 to 2017. Euro Surveill. 2018;23:1800516.

5. Estudio EPINE-EPPS 2017. Informe Global de España. EPINE Workgroup. Sociedad Española de Medicina Preventiva, Salud Pública e Higiene; 2017.

6. Rojo MP, Perujo ES. Vigilancia de la infección quirúrgica: cuál es el método ideal? Enferm Infecc Microbiol Clin. 2014;32:477-8.

7. Pérez CD, Rodela AR, Jodrá VM; Quality Control Indicator Working Group. The Spanish national health care-associated infection surveillance network (INCLIMECC): data summary January 1997 through December 2006 adapted to the new national healthcare safety network procedure-associated module codes. Am J Infect Control. 2009;37:806-12.

8. Díaz-Agero-Pérez C, Pita-López MJ, Robustillo-Rodela A, Figuerola-Tejerina A, Monge-Jodrá V, Grupo de Trabajo INCLIMECC de la Comunidad de Madrid. Assessment of the surgical site infection in 14 hospitals of the Madrid Region: an incidence study. Enferm Infecc Microbiol Clin. 2011;29:257-62.

9. García-Rodríguez JA, Prieto J, Gobernado M, Mensa J, Aranza JR, Domínguez-Gil Hurlé A, et al. Consensus statement on surgical chemoprophylaxis. Rev Esp Quimioter. 2000;13:205-13.

10. Colás-Ruiz E, Del-Moral-Luque JA, Gil-Yonte P, Fernández-Cebrián JM, Alonso-García M, Villar-Del-Campo MC, et al. Incidence of surgical site infection and risk factors in rectal surgery: a prospective cohort study. Cir Esp. 2018:96:640-7.

11. Pastor C, Baek JH, Varma MG, Kim E, Indorf LA, Garcia-Aguilar J. Validation of the risk index category as a predictor of surgical site infection in elective colorectal surgery. Dis Colon Rectum. 2010;53:721-7.

12. Wick EC, Gibbs L, Indorf LA, Varma MG, Garcia-Aguilar J. Implementation of quality measures to reduce surgical site infection in colorectal patients. Dis Colon Rectum. 2008;51:1004-9.

13. Kirchhoff $P$, Clavien PA, Hahnloser D. Complications in colorectal surgery: risk factors and preventive strategies. Patient Saf Surg. 2010;4:5.

14. Alfonso JL, Pereperez SB, Canoves JM, Martinez MM, Martinez IM, Martin-Moreno JM. Are we really seeing the total costs of surgical site infections? A Spanish study. Wound Repair Regen. 2007;15:474-81.

15. Pérez-Blanco V, García-Olmo D, Maseda-Garrido E, Nájera-Santos MC, García-Caballero J. Evaluación de un paquete de medidas para la prevención de la infección de localización quirúrgica en cirugía colorrectal. Cir Esp. 2015;93:222-8.

16. Poon JT, Law WL, Wong IW, Ching PT, Wong LM, Fan JK, et al. Impact of laparoscopic colorectal resection on surgical site infection. Ann Surg. 2009;249:77-81.

17. Sandini M, Mattavelli I, Nespoli L, Uggeri F, Gianotti L. Systematic review and meta-analysis of sutures coated with triclosan for the prevention of surgical site infection after elective colorectal surgery according to the PRISMA statement. Medicine (Baltimore). 2016;95:e4057.

18. Howard DP, Datta G, Cunnick G, Gatzen C, Huang A. Surgical site infection rate is lower in laparoscopic than open colorectal surgery. Colorectal Dis. 2010;12:423-7.

19. Kagawa Y, Yamada D, Yamasaki M, Miyamoto A, Mizushima T, Yamabe K, et al. The association between the increased performance of laparoscopic colon surgery and a reduced risk of surgical site infection. Surg Today. 2019;49:474-81.

20. Kiran RP, El-Gazzaz GH, Vogel JD, Remzi FH. Laparoscopic approach significantly reduces surgical site infections after colorectal surgery: data from national surgical quality improvement program. J Am Coll Surg. 2010;211:232-8.

21. Domínguez EB, Santos RS, Jueguen SD, Teijeiro AP, Antelo JS, Dacosta EC. Impact of preoperative oral nutrition therapy in patients undergoing surgery for colorectal cancer. Nutr Hosp. 2019;36:1150-6.

22. del Manzanares Campillo MC, Fernández JM, Salas MA, Rituerto DC. Estudio prospectivo y randomizado sobre inmunonutrición oral preoperatoria en pacientes intervenidos por cáncer colorrectal: estancia hospitalaria y costos sanitarios. Cir Cir. 2017;85:393-400.

23. Knapp S. Diabetes and infection: is there a link? A mini-review. Gerontology. 2013;59:99-104.

24. Silvestri M, Dobrinja C, Scomersi S, Giudici F, Turoldo A, Princic E, et al. Modifiable and non-modifiable risk factors for surgical site infection after colorectal surgery: a single-center experience. Surg Today. 2018; 48:338-45. 
25. Drosdeck J, Harzman A, Suzo A, Arnold M, Abdel-Rasoul M, Husain S. Multivariate analysis of risk factors for surgical site infection after laparoscopic colorectal surgery. Surg Endosc. 2013;27:4574-80.

26. Gomila A, Carratalà J, Camprubí D, Shaw E, Badia JM, Cruz A, et al. Risk factors and outcomes of organ-space surgical site infections after elective colon and rectal surgery. Antimicrob Resist Infect Control. 2017;6:40.

27. Chida K, Watanabe J, Suwa $Y$, Suwa H, Momiyama M, Ishibe A, et al. Risk factors for incisional surgical site infection after elective laparoscopic colorectal surgery. Ann Gastroenterol Surg. 2019;3:202-8.

28. Han J, Wang Z, Wei G, Yi B, Ma H, Gao Z, et al. Risk factors associated with incisional surgical site infection in colorectal cancer surgery with primary anastomosis. Zhonghua Wai Ke Za Zhi. 2014;52:415-9.

29. Pedroso-Fernandez $Y$, Aguirre-Jaime A, Ramos MJ, Hernández M, Cuervo M, Bravo A, et al. Prediction of surgical site infection after colorectal surgery. Am J Infect Control. 2016;44:450-4.
30. Itatsu K, Sugawara G, Kaneoka Y, Kato T, Takeuchi E, Kanai M, et al. Risk factors for incisional surgical site infections in elective surgery for colorectal cancer: focus on intraoperative meticulous wound management. Surg Today. 2014;44:1242-52.

31. Soriguer F, Goday A, Bosch-Comas A, Bordiú E, Calle-Pascual A, Carmena $R$, et al. Prevalence of diabetes mellitus and impaired glucose regulation in Spain: the Di@bet.es study. Diabetologia. 2012; 55:88-93.

32. Cuthbert CA, Hemmelgarn BR, Xu Y, Cheung WY. The effect of comorbidities on outcomes in colorectal cancer survivors: a population-based cohort study. J Cancer Surviv Res Pract. 2018;12:733-43.

33. Boakye D, Rillmann B, Walter V, Jansen L, Hoffmeister M, Brenner H. Impact of comorbidity and frailty on prognosis in colorectal cancer patients: a systematic review and meta-analysis. Cancer Treat Rev. 2018;64:30-9. 